\title{
Between Beijing and Washington: Israel's Technology Transfers to China
}

\author{
Yoram Evron
}

\begin{abstract}
Technological ties between Israel and China have always been a central and constant element of their relationship. Defense contracts played a leading role here but were also responsible for the severe crisis that erupted between the countries in the early 2000s after Israel, capitulating to US pressure, backed off from its commitment to provide China with military technologies. This not only forced Israel to sever its defense relations with China but also made US-Israel relations a principal factor in the Sino-Israeli connection and imposed tight constraints on Israel's technology transfers to China generally. For Israel, this placed the dilemma of commercial versus political and national security interests at the forefront, since technology connections allowed it to promote its economic, political, and strategic causes through China. Indeed, while technology ties between the states have not stopped entirely-they have shifted to the civilian sphere-technology transfers to China are subject to heavy limitations, and Israel's export control mechanism faces greater challenges to screen them. As China's economic and political influence is ever increasing, Israel's cautious approach to technology transfers to China may be expected to come under mounting pressure. KerwORDS: China-Israel, China-Middle East, technology transfer, export control, defense industry
\end{abstract}

TeChNological ties between IsRael and China haVe been a CENTRAL and constant element since the start of their relationship in the late 1970 s, as Israel expected that in addition to economic benefits they would also serve its political and strategic interests. This was the situation before full diplomatic relations were formed in 1992, and it continues today. However, unlike many other countries, defense contracts played a leading role in the early stages of the technological relations, and due to Israel's export control structure at the time, Israel's Ministry of Defense (MOD) exerted strong influence on the 
conduct of these relations. Technological connections between the countries also ignited full-blown crises between them, above all the Israeli cancellation of the agreement to supply China with the Phalcon Airborne Early Warning and Control system in 2000 due to Israeli capitulation to US pressure. Due to rising US tension with China, this deal, together with Israel's consent in 2005 to conduct maintenance work (or upgrading, according to US accusations) on several Harpy unmanned aerial vehicles (UAVs) it had previously sold to China, pushed the United States to apply its great leverage against Israel's technology transfers to China: it forced Israel to sever its defense relations with China, to subject its technology transfers to China to US screening, and to revise its export control mechanism. The United States thereby not only wrought changes in particular deals by Israel, but even altered domestic institutions. That way, the defense crises did more than unsettle relations between Israel and China, and between Israel and the United States. They also turned US-Israel relations into a principal factor in the Sino-Israeli connection, and placed at its forefront the dilemma of commercial versus political and national security interests.

Consequently, in 2005 defense relations between Israel and China were severed, and Israel wholly revised its position on technological and defense relations with China: in addition to tight restrictions on defense technology transfers to China, it also downgraded military relations to a minimum and screened its exports to China through a much stricter export control mechanism. Nevertheless, this did not halt technology ties between the states. China's interest in Israeli technologies remained high, however (Liu and Fan 2000; Ren, Li, and Liu 2005; Wang Hui 2002; Wang Xinming 2002; Zhang, Zhang, and Yu 2007), and it responded pragmatically to Israel's shifting approach. It blamed the United States for the break in military ties by interfering in China's relations with other countries, and it adopted a forgiving attitude toward Israel, implying recognition of its weakness vis-à-vis the United States (Orme 2000). In addition, dispelling Israeli concerns that China would retaliate for the cancellation of the defense deals by suspending economic ties (Ben 2001; Fishman 2004), Chinese officials have continued to express interest in technological cooperation (Dagoni 2005). Consequently, technology ties between China and Israel continued through civilian channels, mostly trade and academic, and since 2010 also through mutual investments. 
These developments place Israel in a quandary. First, China evidently has not abandoned hope that a change in diplomatic circumstances will one day favor the renewal of its defense technology connections with Israel. Accordingly, Chinese officials continue to call for their resumption and even point out that this might be key in reducing Israel's trade deficit with China. ${ }^{1}$ Second, the defense technology relations in the early days heightened the intimacy between the Israeli and the Chinese leaderships, which to some degree allowed Israel to promote its causes through China. This line of thinking might prove valuable again, as China's involvement in the Middle East, as well as its global influence, grew greater. In addition, as the channels of technology transfer to China diversified, Israel's export control mechanism faced greater challenges. The overall result today is that Israel's cautious approach to technology transfers to China is coming under mounting pressure.

Caught in a triangular relationship with two world powers, Israel's choices in its technological relations with China bear considerable weight for its political and security interests. To comprehend how these choices are shaped, various questions should be explored: What role do technological ties play in Sino-Israeli relations? What is their scope and in which fields do they exist? To what limitations are they subject? What bureaucracies and political players are involved in policy- and decisionmaking on technological relations with China? And what adjustments have been made in the field of technological relations over the years?

To answer these questions, I examine the technological relations between the two countries before and after the Phalcon and Harpy crises, while regarding them as watersheds in both Sino-Israeli relations and Israel's export control regime. My main findings are that due to the central role of the MOD in Israel's export control regime and its emphasis on relations with the United States, Israel's technological relations with China will remain subject to US influence for a considerable time to come. On the other hand, expanding economic relations between China and Israel, as well as China's increasing global influence, generate strong pressures against the existing restrictions and the new modes of technology transfers. All these confront Israel's export control with new challenges, and exacerbate the dilemma of Jerusalem's relations with Beijing and Washington. 


\section{Setting the Stage: Israel's Approach to Technology Transfers Until the Early 2000s}

Since the 1960s, technology transfers have been a major tool in promoting Israel's economic, diplomatic, and security interests (Avimor 1987; Decter 1977). Israel evidently enjoys adequate conditions to develop an advanced technology sector: a culture that promotes entrepreneurship and innovation, an advanced scientific framework, supporting policies, and a large body of experienced professionals trained during their military service in technology units. The dearth of natural resources and absence of conditions to develop large-scale industries are further incentives for development in this field (Breznitz 2006, 1-36; Rivlin 2011, chap. 5; Senor and Singer 2009).

Due to the small size of the local market, most products of this sector are destined for export, and a significant share in the export of technology is held by defense products. Early in its existence, Israel worked to create an advanced defense industry that would grant it a constant technological advantage over its enemies and reduce its dependence on foreign suppliers (Kagan et al. 2010, 228-254; Tal 1996, 70-73). When it was compelled to shift a significant part of its military acquisition budgets to US suppliers following the aid agreements signed between the two states, Israel's defense industries had no choice but to export an increasing percentage of their products (Mintz and Steinberg 1989, 146). And indeed, accumulating experience with both Western and Soviet defense technologies, and willing to supply its clients with not only complete systems but also production technology, Israel became an attractive option for developed and developing countries alike. Its experience in upgrading projects, which could reduce procurement costs, and the proven battle-worthiness of its weapons promoted its defense exports even further (Lifshitz 2000, 468; Shichor 1998, 73-74). As a result, in remarkable contrast to other arms manufacturers in the world, defense exports became the main source of income for Israel's defense industry - exceeding 70 percent - and Israel became a significant world arms exporter (Coren 2011; Lifshitz 2000, 465-476; SIPRI Arms Transfers Database 1990-2012). ${ }^{2}$

Besides its economic role, Israel utilizes defense technology transfers to enhance its national security and political interests (Klieman 1985, 35-47; Lifshitz 2000, 474). Since Israel's establishment, its foreign and defense policies have been dominated by the goals of breaking its diplomatic isolation and lowering the level of military threat it faces. While increasing the financial resources required to 
maintain its qualitative military advantage, defense technology transfers, including homeland security (HLS) and dual-use technologies, have also served to promote its security and diplomatic objectives in several more ways. Probably most importantly, military trade brings together the defense leaderships, and sometimes the top leaderships, of the supplier and client countries. The supplier is exposed to some of the most sensitive secrets of the client country, including those concerning the regime's survival. The trust and sometimes dependence thus created serve Israel in several ways. Diplomatically, even if formal relations between Israel and a given state remain low-level, in many respects that state removes itself from Israel's circle of enemies. It will not join in anti-Israel initiatives, and-as was the case with China-may reduce its criticism against it. In the security aspect, military transfers can be used to enhance relations with countries with which Israel shares common enemies: such was the case with Iran until the Islamic revolution in 1979. Thus the military export connection not only enhances cooperation between the countries, but through Israel's strengthening of its client militarily it magnifies the threat to its foes. Similarly, defense relations allow Israel to use its client's resources (including territory and military intelligence) to promote its military and strategic objectives. For example, it was reported that Israel's substantial arms deals with Azerbaijan are intended, among other things, to allow Israel to operate from its territory against Iran (Cohen 2012). Finally, as was the case with China's arms exports to the Middle East, it allows Israel to influence the recipient state to adjust its behavior in accordance with Israel's interests.

How far such goals can be realized depends largely on the distress level of the client country and the scope and nature of the defense technology transfers. Broadly speaking, the less developed and the more isolated the receiving country is, and the less legitimacy its regime has, the less access it has to advanced defense technology. In such cases, a country willing and able to provide it with the technology it requires enjoys relatively large leverage. On the other hand, countries that meet these conditions tend not to be stable. Their export control mechanisms might be weak and the technology they acquire can be leaked to third parties. If the regime falls the technology may end up in the wrong hands altogether. In addition, if client countries' defense relations are revealed, their dubious legitimacy or their participation in active conflicts may lay the supplier country open to international criticism. 
Until the revision of Israel's export control regime in 2006-2007, the criteria for licensing a defense technology export centered almost entirely on security considerations and the promotion of defense exports as a means to strengthen the local defense industry. The principal reason for blocking a defense export was the possibility of sensitive-technology leakage to hostile countries or nonstate organizations. By contrast, considerations such as nonproliferation norms and diplomatic sensitivity played a minor role (Eilam 2007). For instance, Israel reportedly supplied defense technologies to South Africa when it was subject to harsh criticism due to its apartheid regime (SIPRI Arms Transfers Database 1985-2012). It also exported military technologies to China despite the Western embargo imposed on the latter. This pattern can be explained by the dominant role of Israel's MOD in granting export licenses during that period.

Until 2006, the licensing of defense-related exports was handled by an MOD unit called SIBAT, which concurrently was responsible for promoting Israel's defense exports (Goods and Services Control Order 5752-1991). Other ministries and government agencies were largely excluded from the licensing process; among these was the Ministry of Foreign Affairs (MFA), which might have warned against possible complications arising from particular arms deals. In sum, defense export licensing was in the hands of a small number of officials, mainly within the defense establishment, who most likely made case-by-case decisions (Eilam 2007). Still, there was a blacklistcountries to which arms export was entirely prohibited due to the risk it might cause to Israel's security. As the Chinese case shows, deleting a country from that list was a decision made at the highest political level.

\section{Sino-Israeli Technological Relations, 1979-2000}

Prior to the first contact between China and Israel in 1979, they were separated by a complete void for nearly three decades, during which time China took a radical anti-Israeli stance due to the latter's close relations with the United States and Beijing's pro-Arab line (Goldstein 1999, 14-20; Shai 2009, 17-24; Xia 2005). ${ }^{3}$ The initial contact was made through an international businessman, Shoul Eisenberg. Having been involved since World War II in infrastructure and industrial projects all over East Asia, Eisenberg was invited to China by Deng Xiaoping as early as 1978. Deng, who led a profound policy shift to restore China's ailing economy, expected Eisenberg to found 
industrial projects in China. For that reason he did not object to Israel, the center of Eisenberg's business empire, being one of the technology sources, the absence of diplomatic relations notwithstanding. The condition was that the connection be maintained in the strictest secrecy. Striving to form an attachment with China, Israel agreed, and Eisenberg became the connecting link between the countries (Trofimov 1997, 52; Yegar 2004, 266).

While Eisenberg brought China industrial and agriculture projects and foreign companies from all over the world, ${ }^{4}$ the main connection he formed between China and Israel was in the defense field. In early 1978, Eisenberg informed the minister of defense, Ezer Weizman, that he could get the Israeli defense industries access to China. As China was on Israel's blacklist with regard to defense export, the issue came up for discussion among Israeli prime minister Menachem Begin, Weizman, and Israel's minister of foreign affairs Moshe Dayan. Eventually, due to concerns about the impact on the local defense industry of the collapse of the Shah's regime in Iran-a major purchaser of Israel's military products hitherto-as well as the assessment that the United States would not object to direct ties between Israel and China, they decided to allow the transfer of defense technologies to China. They also resolved to keep these relations highly confidential.

Another important decision, which demonstrates how defense export was decided and executed, concerned the role of Eisenberg. Because Israel had no direct links to China, Begin, Weizman, and Dayan decided to use an international Israeli businessman to mediate between China and the local defense industries; Eisenberg's strong ties with China made him the leading choice. However, he demanded exclusivity in conducting these transactions, and a relatively high commission (above 15 percent). In return, he offered not only his close connections with China's top leadership but also significant logistic and financial support: he allowed MOD officials and defense industry executives and experts to make use of his private 707 Boeing for their journeys to China, thereby keeping them secret. Eventually, his terms were accepted (Barzilai 1999, 28-30; Yegar 2004, 264). ${ }^{5}$

All in all, until 2000, when the first crisis in their defense relations erupted, Israel and China conducted more than sixty defense deals-presumably some of them interconnected-whose total worth, based on conservative estimates, was US\$1-2 billion (Schiff 2005; Shichor 1998, 69-72). ${ }^{6}$ According to unconfirmed reports, by 
2000 Israel had supplied China with the technology to upgrade its T59-type tanks, night vision systems, radio systems, electronic warfare systems, air-to-air missiles, a technology derived from the Lavi fighter (whose development in Israel was halted in the late 1980s), antiradar assault UAVs (Harpy), and more. According to the same reports, these deals included-in addition to the hardware-manufacturing and integrating know-how as well (Barzilai 1999, 32; Kumaraswamy 1994, 43; Shichor 1998, 74; SIPRI Arms Transfer Database 1979-2000). During the 1990s, following the reconciliation between Beijing and Moscow and China's consequent access to advanced Russian bargain-price weapons, Israel's defense exports to China declined.

In addition to direct defense technology transfers, the two countries also conducted civilian activities through which Israeli technology was transferred to China. In the commercial sphere Eisenberg's channels were used to introduce Israeli companies and technologies, including a bromine factory, advanced textile production know-how, and agricultural know-how of different types. Another channel was an Israeli government mediating company, COPECO, established in 1987 , which engaged in civilian projects mainly in agriculture (Shalhevet 2009, 123-139).

After the establishment of diplomatic relations in 1992, the total trade range between China and Israel began to expand, although until 2000 it did not exceed US\$1 billion. Furthermore, most of China's exports to Israel in bilateral trade consisted of low-cost consumer goods (Israel Central Bureau of Statistics 1992-2012). Israel and China also started to cooperate in basic and applied scientific research. One of the distinct expressions of the importance assigned to this aspect of their relations was the 1990 opening in Beijing of the Israeli Science Academy Liaison Department, which also served as the official representation of Israel before diplomatic relations were formed. Its activities covered several areas of scientific cooperation: agriculture, public health and rehabilitation, protection of the environment and conservation of natural resources, development of arid areas, and utilization of alternative sources of energy (Shalhevet 2009, 10-13, 22, 77-81). After the establishment of diplomatic relations the Academic Center was dissolved, but scientific cooperation continued albeit on a small scale.

All in all, the first period of technological relations between the two countries left an important legacy: China was exposed to Israel's technological capabilities, the two sides got to know each other, and 
a solid basis was laid for their future cooperation. The defense technology transfers played a major role in these relations, incorporating business with national interests. This turned the Israeli MOD into a major player here due to its role in the supervision of Israel's defense exports. On the other hand, the high barriers between the defense and civilian sectors in Israel limited the positive effect that the close defense relations might have had on other fields, and bilateral civilian technological interactions remained limited. Moreover, the conduct of defense relations with China for over two decades without external interruption-despite their sensitivity-led Israel's defense establishment to assume that the existing mode of operation could last.

\section{The Defense Crises and Their Implications}

In July 2000 the first crisis between China and Israel erupted when Israel yielded to US demands and informed China that it could not complete the Phalcon deal due to uncompromising US pressure. According to the agreement signed between the two countries in 1996, Israel was to provide China with the Phalcon Airborne Early Warning (AEW) and control system, developed by Elta, a subsidiary of Israel Aerospace Industries (IAI), and mounted on the Russian Beriev A-50 aircraft. The Phalcon system was based on radar with phased array antennas and comprised advanced electronic systems, which, in addition to early warning, provided tactical surveillance of airborne and surface targets as well as signal intelligence (SIGINT) gathering.

The first US public demand to cancel the deal was made in 1999 after the A-50 aircraft arrived in Israel from Russia. The underlying claim was that the Phalcon would alter the strategic balance in the Taiwan Strait in favor of China and was liable to increase the number of US casualties if US forces became involved in a military conflict that might erupt there. Pointing to the huge amount of aid it had given to Israel over the years, and the close relations between their defense establishments, Washington demanded of Jerusalem not to deliver such a system to China.

At first, Israel believed it could parry US pressure, relying on the fact that the system did not include protected US technology-a claim Washington has never challenged (Orme 2000). It argued that it had informed Washington about the deal in advance and had won its approval. The Israeli prime minister, Ehud Barak, even intimated 
to the Chinese president, Jiang Zemin, who traveled to Israel in April 2000 to secure the deal, that it would be completed. However, unaware of the growing resentment toward China in the United States in the late 1990s, Israel did not evaluate correctly the degree of resistance that the deal would encounter in Washington. Eventually, facing implicit US threats to cut its military aid, and seeking US support in its negotiations with the Palestinians at that time, in July 2000 Israel announced the cancellation of the deal (Fulghum 2000, 45; Kumaraswamy 2005, 93-103). From Israel's perspective, this move, and more especially the personal insult to the Chinese president, misled by the implicit promise by the Israeli prime minister, raised a twofold concern. First, its credibility as a world-level supplier of defense products would be damaged-a fear that in the event proved unfounded. Second, Israel was gravely and particularly anxious about the damage caused to its relations with China. This anxiety was justified. However, despite the setting up of consultation mechanisms between the Israeli MOD and US Department of Defense and State Department on issues of defense exports to China, Israel's export control system did not undergo any comprehensive change for the time being.

The second crisis occurred in 2005 following Israel's agreement to conduct maintenance work on IAI's Harpy assault UAVs, originally sold to China in the late 1990s. This crisis was graver than the previous one due to the US demand that Israel not send back the UAVs that China had already shipped to it. Washington also asserted that Israel had tried to deceive it-naming top MOD officials as stating that the UAVs had been brought in for maintenance, when in fact they were to be upgraded (Shichor 2005, 7-9). More broadly, Washington required Israel first to completely suspend its defense technology relations with China; second, to provide the United States with a detailed report on its military transfers to China; and third, to sign with the United States a memorandum of understanding establishing that US approval was requisite for any defense and dual-use exports to China (Caspit 2005; Schiff 2005). The understandings went even further, as Israel's list of banned technologies to China became more comprehensive than that of the United States, and Washington demanded that the top MOD officials involved in the Harpy affairmost notably the MOD's director general-be removed from office (Caspit 2005; Opall-Rome 2011).

Aside from the defense field, the curtailing of Sino-Israeli defense relations dealt a mighty blow to the countries' diplomatic 
relations. First, it discredited Israel, which hitherto China assumed had much greater influence in Washington and for this reason, among others, sought close relations with it (Yegar 2004, 271). Second, the defense relations served not just as a source of capital for Israel's defense industries, but also as a means to influence China's arms proliferation in the Middle East. In the 1980s Israel had managed to persuade China to halt ballistic missile transfers to Arab countries, itself stopping arms sales to Taiwan in return (Israel Ministry of Foreign Affairs 1992-1994; Shichor 1998, 78). In that respect, the severance of their defense technology relations had significant implications: it left Israel with no substantial means to influence China's moves in the Middle East, especially as China's involvement in the region started to deepen in the 2000s (Pan 2010, 82-88; Schenker and Lin 2010; Simpfendorfer 2010). Third, it made Israel an active player in the sharpening Sino-US rivalry.

On a larger scale, the United States insisted that the Israeli export control system undergo a fundamental change, arguing that the Phalcon and Harpy crises were the outcome of the MOD's overarching dominance of Israel's export licensing (Oren 2005). According to Washington, the predominant status of the MOD in the government, as well as the oversight of export licensing by an MOD ministerial order, allowed that ministry to treat this domain as an internal ministerial matter. Under such conditions, the defense industry's economic interests were given excessive precedence over all other considerations; other ministries were not always even aware of export licensing decisions, let alone able to block them.

The outcome is the 2007 Export Control Law and the accompanying ministerial orders, which created a wider and better-based framework for Israel's export control regime (Defense Export Control Law; Import and Export Order 5764-2004; Import and Export Order 5766-2006). Broadly speaking, the new regime is highly detailed. It extends the range of activities requiring licenses, and leaves room for additional factors and considerations aside from national defense, including international norms and rules on arms control. In particular, while Israel is not party to the Wassenaar Arrangement (WA) on conventional military means and dual-use technologies, or to the Missile Technology Control Regime (MTCR), the new law includes the constraints embedded in these regimes. In addition, the Defense Export Control Law provides for extremely grave penalties for any entity attempting to export defense products to a body banned by the UN Security Council (Articles 2, 15, 32, 33). 
Adjustments to the export control regime were also made on the administrative level. In 2006 the authority to grant export licenses was removed from SIBAT and transferred to a new body in the MOD set up especially for this purpose: the Defense Export Control Directorate (DECD). ${ }^{7}$ Thus, the conflict of interests arising from SIBAT's responsibility for both promoting Israel's defense export and handling export control was resolved. At the same time, the MOD lost its monopoly on export licensing, as under US pressure the MFA and the Ministry of Industry, Trade, and Labor (MOITAL) were officially incorporated into the process (Defense Control Law, Articles 24(b)(3), 27). ${ }^{8}$ However, as DECD is an MOD subunit, the MOD remains the leading body in the export control regime, but because defense exports per se to China were banned, MOITAL's importance with regard to export to China has increased (see Figure 1).

\section{Sino-Israeli Technological Relations After the Defense Crises}

Contrary to Israeli concerns, China did not retaliate for the cancellation of the Phalcon deal by damaging their economic relations, and the countries' trade relations continued undisturbed. From a total value of approximately US $\$ 860$ million in 2000 , the trade volume between them tripled within five years, reaching over US $\$ 8$ billion by 2012 , with China becoming Israel's second-largest trading partner. In addition, since the early 2000s, Israeli venture capital (VC) funds began to operate in China and new agreements on technological cooperation were signed; in the second half of the decade $R \& D$ activities by Chinese companies in Israel were initiated. All these created new channels for the transfer of Israeli technology to China, which in view of the link between China's civilian and defense industries as well as the growing role of civilian technologies in defense products, posed fresh challenges to Israel's export control regime. These challenges went beyond the types of restrictions the United States imposed on Israel and aggravated Israel's quandary on technological relations with China.

\section{New Channels of Technology Transfers}

Export to China. With the severing of defense relations, Israeli high-tech and mixed advanced technology companies became an important channel for transferring technologies between the coun- 
Figure 1 Export Licensing Process

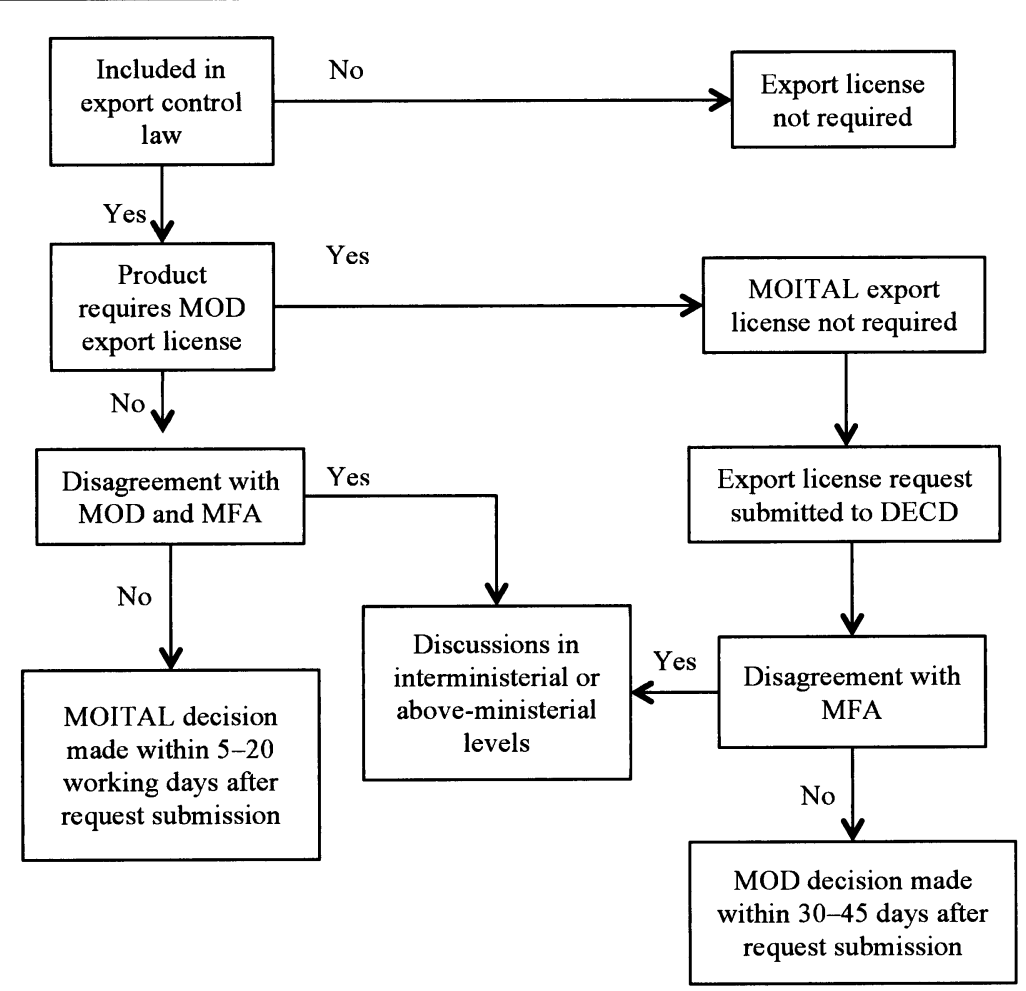

Source: MOITAL, "Export Control”; Defense Export Control Order (Licenses), 5768-2008.

tries. Hundreds of Israeli high-tech companies-mostly in the fields of medical equipment, information and communication technologies (ICT), agricultural technology, control and measurement equipment, machines, and electrical engines-export their products to China, with a significant number of deals involving the transfer of production technology. As the Chinese market has become ever more competitive, and Israeli companies are hard pressed to resist their customers' demands, they have often been willing to reveal the basic components of their products-for instance, the source code of their products' software-to secure a deal. ${ }^{9}$

Thus, as most Israeli export to China comprises high-tech and mixed high-tech products and technologies, bilateral trade can be 
regarded as an important channel of technology transfer. ${ }^{10}$ Between 2008 and 2011, high-tech goods accounted for some 50-60 percent of total exports. In these technologies, most notable is the category of electrical machinery, equipment, and parts, which accounts for more than 50 percent of Israel's high-tech exports to China and about 30 percent of total exports. Dominant in this category are electronic integrated circuits and microassemblies (30-60 percent of exports in this category) and electrical components for communications systems (10-15 percent) (Israel Central Bureau of Statistics 2008-2011).

Being integrated in a large variety of systems, these products and components can contribute to the development of China's telecommunications, aerospace, and other industries. These fields are at least partly related to the defense sector, and since the 1990s they have been considered an important source of advanced technology for China's military modernization (Cheung 2009, 201-222; Cliff 2001). So although classified as civilian, these technologies can nevertheless be relevant to the development of China's national defense capabilities in fields such as command, control, communication, computers, intelligence, surveillance, reconnaissance systems (C4ISR), cyber warfare, and the like.

Nevertheless, this channel probably plays only a limited part in Israeli technology transfers to China, due to China's tough and competitive business environment, as well as the exporting companies' concern over intellectual property rights (IPR) violations, Israeli export to China is limited (Coren 2007, 68-80). In 2009, twentythree of the fifty-three largest exporters in Israel in the high-tech sector were not among the top 100 Israeli exporters to China despite the fact that their product matched China's import profile. Moreover, about 70 percent of Israeli exports to China are from two companies only: Intel (Israel), which exports its products to Intel's subsidiary in China, and Israel Chemicals, which mostly exports fertilizers and minerals for the agrarian market (Israel Export and International Cooperation Institute 2010, 2007).

Israeli R\&D activity in China. A more substantial channel of Israeli technology transfer to China is R\&D collaboration between companies and academic institutions of both states, as well as R\&D activity of Israeli companies in China. In the early 2000s, Israeli government bodies and VC firms started to promote technological-commercial cooperation between companies in the two states. VC activity in 
China has sought to promote collaboration between Israeli and Chinese companies, including joint ventures in which the Israeli partner supplies the technology and the Chinese partner is responsible for the introduction of the product into the local market (CIVC company overview; Infinity company overview; Orbach 2011). As for Israeli government organizations, first, these persist in their efforts to establish joint academic research and exchange programs, and various cooperation agreements have been signed between academic and research institutes in the two countries. These initiatives include the grant of hundreds of scholarships to Chinese graduate students in science and engineering. In addition, the national academic science foundations in the two countries signed an agreement in 2012 to support joint research projects in science and engineering (Council for Higher Education). While the projects are purely academic, some of them, for example, in nanotechnology, new materials, and satellite technology, can be of military relevance ("The Language of Science" 2007-2008).

Second, Israel signed cooperation agreements in R\&D activity with the Chinese government, as well as with individual Chinese state agencies, provinces, and major municipalities (MATIMOP 2011). Like the academic projects, some collaborations conducted through this channel-including projects in the fields of information technologies and software, data telecommunications, opto-electronics, and advanced automation aerospace-might have military relevance. Finally, technology transfers are conducted through R\&D centers that Israeli companies operate in China. Apparently, however, such activity is not large scale, mainly due to the Israeli companies' concern over IPR violations, as well as their inclination to keep R\&D at home.

Chinese R\&D and investments in Israel. The third channel of technology transfer to China is Chinese companies' activity in Israel, through investments in Israeli technology firms or establishing R\&D centers in Israel. The first attempts to attract Chinese companies to set up development centers in Israel were made already in the early 2000s (Manor 2004), but only a decade later was the first such center established-by Huawei. Yet to date Huawei remains the sole Chinese company to have done so, and moreover, it is discreet about it. To keep its activity in Israel low profile, it manages its development activity through a privately owned Israeli company, Toga Net- 
works, which was established in 2009 and officially supplies design and development services to international customers, even though Huawei is known to be its only client (Grimland 2011; Shelah 2010).

The reason for this course of action is not clear, nor is it clear why other Chinese companies refrain from setting up development centers in Israel, which is considered in China a source of advanced technologies. One possible reason, which cannot be empirically supported but is consistent with the prevailing circumstances, is that Chinese technology companies are deterred by the close relationship between Israel and the United States, and they are concerned that their activity in Israel would be subject to close scrutiny. Another is Huawei's fears of a negative impact in Muslim states in which it is active. Nevertheless, even under the tight conditions in which the Huawei development center operates in Israel, it enjoys access to valuable technological know-how. Evidently, Huawei attracts highlevel and experienced employees of Israeli IT companies with the offer of high salaries and tries to recruit employees at the local development centers of its global competitors (e.g., Cisco Systems, Marvell Technology Group) (Shelah 2010).

Another method of importing Israeli technology into China is through investment in and acquisition of Israeli companies by Chinese companies. Proposals by the latter to the former for technological collaboration are one form of this activity, and in contrast to earlier initiatives, presently Chinese companies also offer to fund Israeli $\mathrm{R} \& \mathrm{D}$ projects in return for the products' marketing rights in China (Gabison 2012; Katsovich 2012). Investments in Israeli companies are conducted through VC funds as well. For instance, the giant computer company Lenovo announced its investment in Vertex $\mathrm{VC}$, whose purpose is to fund Israeli companies in stationary and mobile communications, digital media, and other fields. As reported, this investment was part of the Lenovo Group's strategic decision to strengthen its presence in Israel (Goldenberg 2012). Finally, Chinese companies have also begun acquiring Israeli companies that possess advanced technologies. The most notable case is the acquisition of 60 percent of the agrochemicals manufacturer Makhteshim Agan Industries by the China National Chemical Corporation (ChemChina). That deal has no direct defense implications, but such a mode of activity can repeat itself in other industries (Rolnik and Azran 2011; Yeshayahou 2011). 


\section{Limits on Civilian Technology Transfers}

While civilian technology transfers to China are subject to far fewer restrictions than defense-related and dual-use transfers, they are still subject to stringent limitations by formal and informal barriers. The revision of the export control system in 2006-2007 carried significant implications for civilian activities due to incorporation of the WA list of dual-use technologies into Israeli law. Under the export control law, Israeli companies planning to export items (products, parts, or know-how) on the WA list are required to apply for an export license. It is the company's responsibility to familiarize itself with the WA list and to submit such an application. Its approval becomes a prolonged and complex process when it concerns Chinese clients. If it is a civilian item the export licensing process is handled efficiently and quickly. But if there is concern that the item is listed in the understandings with the United States on export limitations to China, the request is forwarded to the MOD and the export licensing process becomes more complicated.

Reportedly, the procedure agreed by Israel and the United States-namely, that the export to China of certain items must be approved by the United States-has become a heavy burden on Israeli exports to China and collaboration with Chinese companies. The approval process by Washington is overlong, so deals occasionally fall through (Opall-Rome 2011). This obstacle, however, is not the result of Washington's attitude alone, but also of the Israeli MOD. In fact, in Israel the MOD is accused of surrendering too comprehensively to US demands, causing damage to the Israeli economy and to diplomatic relations with China (Coren 2008; Melman 2008; Zeevi 2008). Being Washington's main target during the defense crisis, the MOD has adopted a radical position against technology transfers to China and has become the chief obstacle to Israeli export there and to technological collaboration between the two countries. According to the critics, unwilling to face Washington's accusations yet again, the MOD takes a harsher line than Washington itself with regard to China, forbidding technology exports that are permitted by the United States. A striking example is the ban on the export of HLS equipment to China, which prevented Israeli companies from participating in the security system at the Beijing Olympics in 2008, while Western companies were highly active there (Zeevi 2008). According to some assessments, as long as the MOD officials who took an active role in the Phalcon and Harpy crises remain at their posts, 
MOD objection to any reexamination of the defense export policy regarding China will be immovable. ${ }^{11}$

Finally, Sino-Israeli technological relations are subject to selfrestraint by Israeli high-tech companies, for many of which the United States is their main center of activity. According to Israeli executives in these companies, they often fear that taking Chinese partners will block the US market to them, and they prefer to avoid the Chinese market altogether (Grimland 2011). This concern prevails not only in companies that develop defense or dual-use technologies but in high-tech companies in general (Coren 2012). As one marketing director explained, a decision to operate in the Chinese market is a strategic one since it may keep the company out of the US market. The reason is not necessarily US regulations or laws, but that US companies and government agencies will not be willing to collaborate with it or buy its products. ${ }^{12}$

\section{Conclusion}

Despite Israel's being forced to cease its defense technology transfers to China in the early 2000 s, challenges remained in the technological relations between the two countries. These were moved to civilian fields and channels, mostly trade, investments, and academic cooperation. However, because of the close linkage in China between the defense and civilian sectors in the areas of the two countries' scientific and technological relations-telecommunications, computers, aviation, nanotechnology, and the like - such relations may still have military implications. But because such transactions are conducted through various civilian channels, their supervision has become more challenging, the strengthening of Israel's export control system notwithstanding. The situation is even further complicated by the absence of any bar to technological cooperation between Chinese and Israeli companies that produce defense and dual-use products, as long as the products under development are civilian.

Aside from the legal-technical challenge of conforming to an efficient export control system, the restrictions on technology transfers to China have created economic and political dilemmas for Israel in its triangular relations with China and the United States. As Israel regards its relations with the latter as one of its greatest assets, following the crisis in this relationship due to its defense ties with China it adopted uncompromising restrictions on defense and dual- 
use technology transfers to China. The restrictions, however, which in fact exceed the limits stipulated in the 2007 Export Control Law, have not only curtailed Israeli defense export to China. They have also put Israeli companies at a competitive disadvantage and deprived Israel of a powerful political and strategic tool vis-à-vis China, as the latter's involvement in the Middle East expands.

Economically, according to executives in Israeli industries, the current restrictions not only worsen Israel's trade imbalance with China, they also weaken Israeli companies against their global competitors, including US ones, which do export their products to China. The export restriction on certain HLS products is only one example.

Similarly, security considerations may induce Israel to block investments by large Chinese corporations in Israeli technology companies (Orbach 2010). This measure may lead to retributive actions against Israeli companies by the Chinese authorities, or leave extensive sections of the Israeli technology sector out of one of the most significant world markets. Such complaints, as well as Israel's economic dilemma, can only be expected to increase as Chinese investments in Israel grow. Since the 2008 global financial crisis, recruiting Western investments in Israel has become increasingly difficult, so Israeli companies will find it ever harder to resist Chinese investments.

From the political-strategic aspect, over the past several years China has gradually increased its involvement in the Middle East. In view of its growing dependence on Middle Eastern oil and its search for greater global influence, this trend will probably continue. Israel, in response, will find it hard to persist in excluding China from its national security and strategic calculations and will probably be forced to seek closer ties with Beijing. Reevaluating the current approach to technology transfers to China-something China has long been calling for-can serve this cause. The dilemma may become even more complex if China's role in the Middle Eastern arms market expands. While China has already been exporting weapons to the region for several decades, Israel has not generally regarded this as a direct threat. And when in the late 1980s China provided Middle Eastern powers with more advanced weapons, mostly missiles, the sound defense relations between Jerusalem and Beijing allowed Israel to persuade China to stop such deliveries. This is probably one of the reasons why Israel, unlike the United States, has not been concerned by China's military development in recent 
decades. However, as China's defense industry progresses and its relations with Middle Eastern states grow firmer, its arms transfers to the region might cause Israel concern. Such a development may encourage Israel to engage in dialogue with Beijing, in which its willingness to reconsider its export restrictions can play a constructive role.

Under such circumstances, the Israeli business community and certain government agencies can be expected to exert pressure to reconsider the current understandings with the United States. The general argument is that adhering to the current policy may hurt Israel's economic and political-strategic interests in the long run, as it may put China out of reach of the Israeli high-tech sector and be conceived by Beijing as Israeli lack of goodwill and disregard for its growing global and regional influence. On the other hand, the new channels of technology transfers are expected to afford China greater access to advanced Israeli technology, and if the challenge is not addressed properly further complications with the United States may arise. Resolving such a dilemma requires new ways of technology transfer supervision, and perhaps also new thinking about the framework of technological relations among the three countries.

Yoram Evron is assistant professor in the Department of Asian Studies at the University of Haifa and a senior research fellow at the Institute for National Security Studies (INSS). He was also a visiting fellow at the S. Rajaratnam School of International Studies (RSIS), Nanyang Technological University. Evron's research interests include theories and practices of China's national security, military procurement, and technological development, as well as China-Middle East relations. His recent article, "China's Military Procurement Approach in the Early Twenty-First Century and Its Operational Implications," was published in the Journal of Strategic Studies in 2012. He holds a PhD in Political Science from the University of Haifa.

\section{Notes}

The first version of this article was presented at the workshop entitled "China's High-Tech Trade and Investment with Major Partners: Channels and Implications," held on July 23-24, 2012, at the University of California's Institute on Global Conflict and Cooperation (IGCC). I am indebted to the organizers and participants in the workshop, in particular Tai Ming Cheung, Bates Gill, and Barry Naughton. I am likewise most grateful to the editor and the reviewers of the Journal of East Asian Studies for their most helpful comments. 
1. Presentation delivered to Israeli businessmen by China's commercial attaché to Israel, Hu Ming, First Annual Conference for Business in China, Ramat Gan, July 27, 2011.

2. Since the early 1990s Israel has been graded by the Stockholm International Peace Research Institute (SIPRI) as one of the top ten defense exporters in the world. However, SIPRI's ranking is based on major conventional weapons supply, while Israel's military export consists largely of military and dual-use subsystems, and of component and upgrade technologies. Israel's defense export, including that to China, is therefore larger than indicated in the SIPRI database (SIPRI Arms Transfers Database 1990-2012).

3. Israel and the People's Republic of China recognized each other in 1950, but did not establish diplomatic relations. After several attempts at rapprochement in the first half of the 1950 s, they remained in a state of complete detachment until 1979.

4. As reported by one of his former executives, Eisenberg was responsible, among other things, for setting up power stations in China, transferring production know-how of high-quality containers, and bringing to China a truck production line. Interview with a former director at the Eisenberg Group of Companies, Tel Aviv, March 25, 2012 (due to the sensitivity of the subject, all interviews conducted for this research were held on condition of interviewees' anonymity).

5. Eisenberg also undertook to sell the goods given by China as payment (mostly silk) and to remit the money to the exporting industries, and sometimes his jet was used to carry equipment and goods related to the ongoing projects.

6. The estimate of the arms sales' value is based on Shichor (1998, 69-72). In 1998-1999 Israel and China concluded the Harpy deal, which was not included in Shichor's estimate, and according to available evidence was the last arms deal between the two countries. However, as the value of the Harpy deal was reportedly US\$55-70 million, Shichor's general estimate remains valid.

7. Also known as the Defense Export Control Directorate or Defense Export Control Agency.

8. MOITAL's title was revised after the 2013 general elections in Israel to the Ministry of Economy.

9. Interview with a director of an Israeli telecommunications company, Tel Aviv, January 12, 2012.

10. Official Israeli export records do not contain a category of high-tech items. However, certain categories can be regarded as such, especially (a) machinery and mechanical appliances and computer equipment; (b) electrical machinery, equipment, and parts; and (c) optical, photographic, measuring, and medical instruments. These three categories are used here to analyze trends of Israeli high-tech exports to China. Other categories, such as pharmaceutical products, may include high-tech products or parts as well, 
but they are either of limited volume or comprise a mixture of advanced and semi-advanced technologies, and therefore were not included in the analysis (Israel Central Bureau of Statistics 1992-2012). See Israel Central Bureau of Statistics, "Exports and Imports, by Commodities and Countries."

11. This claim is based on background interviews with government officials, but this cannot be verified empirically.

12. Interview with a director of a high-tech company, Tel Aviv, May 27, 2013.

\section{References}

Avimor, Shimon. 1987. Israel's Technical Assistance to Cambodia, 19651975. S.I.: S.N.

Barzilai, Amnon. 1999. "Kaha Portzim Homa" [This is how a wall is penetrated]. Haaretz Magazine, February 5, 26-32.

Ben, Aluf. 2001. "Barak Poel Lehadesh et Iskat HaPhalcon" [Barak tries to renew the Phalcon deal]. Haaretz, January 31.

Breznitz, Dan. 2006. "Innovation-Based Industrial Policy in Emerging Economies? The Case of Israel's IT Industry." Business and Politics 8, 3: $1-36$.

Caspit, Ben. 2005. "Amos Yaron Yifrosh-Veyetze Lebikur Rishmi Be Washington" [Amos Yaron will retire-and will conduct an official visit in Washington]. Maariv, July 11.

Cheung, Tai Ming. 2009. Fortifying China: The Struggle to Build a Modern Defense Industry. Ithaca: Cornell University Press.

CIVC (company overview). www.civcfund.com/about/?did=7 (accessed March 18, 2012).

Cliff, Roger. 2001. The Military Potential of China's Commercial Technology. Santa Monica: RAND.

Cohen, Gili. 2012. "Israel Tesapek Neshek Le'Azerbaijan Beshovi 1.6 Milliard Dollar" [Israel will supply $\$ 1.6$ billion worth of weapons to Azerbaijan]. Haaretz, February 27.

Coren, Ora. 2007. "Haim Shanghai Mechaca Li?” [Is Shanghai waiting for me?]. The Marker Magazine, April, 68-80.

- 2008. "Israeli Exports Missed the Boat to China." Haaretz, January 3.

- 2011. "Defense Exports Shifting Focus to New Areas." The Marker, February 15.

—. 2012. "Sin: Shituf-Peula Im Ha'High-tech Ha'Israeli-Mnoa Tzmicha Movil" [China: Cooperation with the Israeli high-tech-a leading growth engine]. The Marker, March 3.

Council for Higher Education. "Academic Cooperation with China and India: General Information.” http://che.org.il/en/?page_id=21246 (accessed May 30, 2013).

Dagoni, Ran. 2005. "Im Sin Osa Asakim BeIsrael, LeArhav Ein Zchut Lehitarev Bahem" [If China does business with Israel, U.S. has no right to intervene]. Globes, April 12-13. 
Decter, Moshe. 1977. To Serve, to Teach, to Leave: The Story of Israel's Development Assistance Program in Black Africa. New York: American Jewish Congress.

Defense Export Control Law, 5766-2007, LSI 2105 (July 26, 2007) (Isr), 398.

Eilam, Uzi. 2007. "Defense Export Control in 2007: State of Affairs." Strategic Assessment 9, 4. www.inss.org.il/publications.php?cat=21 \&incat $=\&$ read=44 (accessed May 14, 2012).

Fishman, Alex. 2004. "Heelu Et Hasaif" [Got on their nerves]. Yediot Ahronot, December 24.

Fulghum, David A. 2000. "Israel Backs Off China AWACS Sale." Aviation Week and Space Technology, July 17, 45-46.

Gabison, Yoram. 2012. "D-Pharm Slashing Staff After Drug Flop." Haaretz, February 2.

Goldenberg, Roy. 2012. "Lenovo Invests in Vertex's New Venture Capital Fund." Globes, February 27.

Goldstein, Jonathan. 1999. "The Republic of China and Israel." In China and Israel, 1948-1998: A Fifty-Year Perspective, ed. Jonathan Goldstein, 1-39. Westport: Praeger.

Goods and Services Control Order (Defense Equipment and Defense KnowHow Export), 5752-1991, KT 5752 (Isr), 609.

Grimland, Guy. 2011. "Haanak HaSini: Oyev O' Yadid?" [The Chinese giant: A foe or a friend?]. The Marker, July 31.

Import and Export Order (Control of Chemical, Biological, and Nuclear Exports), 5764-2004, KT 6306 (Isr), 387.

Import and Export Order (Control of Dual-Purpose Goods, Services and Technology Exports), 5766-2006, KT 6517 (Isr), 1174.

Infinity (company overview). www.infinity-equity.com/about.asp (accessed March 18, 2012).

Israel Central Bureau of Statistics. "Foreign Trade." www.cbs.gov.il/reader /?MIval=cw_usr_view_SHTML\&ID=461 (accessed July 22, 2013).

Israel Export and International Cooperation Institute. 2007. "100 Hayetzuanim Hamovilim Bataasiya haIsraelit, 2007" [The leading 100 exporters in the Israeli industry, 2007]. www.moit.gov.il/NR/rdonly res/EA271A7D-2E65-45E0-B92E-6A41B1D074F0/0/yetzuanim07 .pdf (accessed March 13, 2012).

- 2010. "Yetzu Schorot Vemutzarim Bein Israel LeSin Baasor Haaharon" [Export of industrial goods and products from Israel to China during the last decade]. Unpublished report.

Israel Ministry of Foreign Affairs. 1992-1994. "Meeting Between Rabin and Qian Qichen." In Israel's Foreign Relations: Selected Documents, Vol. 13-14. http://mfa.gov.il/MFA/ForeignPolicy/MFADocuments/Year book9/Pages/15\%20Summary \%20of\%20a\%20meeting\%20between \%20Prime\%20Minister\%20Rab.aspx (accessed May 31, 2013).

Kagan, Kobi, Oren Setter, Yoad Shefi, and Asher Tishler. 2010. "Defence Structure, Procurement and Industry: The Case of Israel." In Defence 
Procurement and Industry Policy: A Small Country Perspective, ed. Stephan Markowski, Peter Hall, and Robert Wylie, 228-254. Oxon: Routledge.

Katsovich, Guy. 2012. "D Pharm Expands Chinese Cooperation Agreement." Globes, January 10.

Klieman, Aharon. 1985. Israel's Global Reach: Arms Sales as Diplomacy. Washington, DC: Pergamon-Brassey's International Defense.

Kumaraswamy, P. R. 1994. "The Star and the Dragon: An Overview of Israeli-PRC Military Relations." Issues and Studies 30, 4: 36-55.

. 2005. "Israel-China Relations and the Phalcon Controversy." Middle East Policy 12, 2: 93-103.

"The Language of Science Bridges the Cultural Gaps." 2007-2008. Technion (Winter).

Lifshitz, Yaacov. 2000. Calcalat Bitahon: Hateoria Haclalit Vehamikre HaIsraeli [Defense economics: The general theory and the Israeli case]. Jerusalem: Jerusalem Institute for Israel Study and Ministry of Defense.

Liu, Jianbo, and Fan Jiannian. 2000. "Yiselie fengxian tuozi de chenggong jingyan" [Successful experience of venture capital in Israel]. Science and Technology Information Development and Economy 10, 1: 11-12.

Manor, Hadas. 2004. "Ulmert Betom Habikur BeSin: Paar Gadol Bein Mimush Haiskaot Lebein Hapotentzial" [Ulmert after his China visit: There is a wide gap between the deals' potential and implementation]. Globes, June 27-28.

MATIMOP, Israel Industry Center for R\&D. 2011. "Israel-China Industrial R\&D Basis for Collaboration." Unpublished report.

Melman, Yossi. 2008. "Kulam Rotzim Kesher Im Sin, Hutz Memisrad Habitahon" [Everyone wants connection to China, except for the Ministry of Defense]. Haaretz, August 21.

Mintz, Alex, and Gerald Steinberg. 1989. "Coping with Supplier Control: The Israeli Experience." In The Dilemma of Third World Defense Industries: Supplier Control or Receipient Autonomy? ed. Kwang-Il Baek, Ronald McLaurin, and Chung-in Moon, 137-151. Boulder: Westview Press.

Opall-Rome, Barbara. 2011. "Israel-China Revive Military Ties, But Not Defense Trade." Defense News, August 17. www.defensenews.com /article/20110817/DEFSECT04/108170302/Israel-China-Revive -Military-Ties-But-Not-Defense-Trade (accessed May 14, 2012).

Orbach, Meir. 2010. "Hahoma Ha'anti-Sinit: Lama Hehashash Mepnei Haanakiot Mehamizrah Mesucan?" [The anti-China wall: Why is the concern over the eastern giants dangerous?]. Calcalist, December 3.

- 2011. "Infinity, China to Invest in Israeli Firms." Calcalist, August 16. www.ynetnews.com/articles/0,7340,L-4109638,00.html (accessed May 16, 2012).

Oren, Amir. 2005. "Arhav Doreshet Lehagbil et Hashpaat Misrad Habitahon al Hayetzu Le'medinot Beayatyot" [The US requires limits on the Min- 
istry of Defense's influence over Israel's export to "problematic states"]. Haaret, June 6.

Orme, William A. 2000. "Israeli Armorer in a Global Arena: Aircraft Maker Runs Afoul of U.S. with China Radar Contract." New York Times, June 30. www.nytimes.com/2000/06/30/business/israeli-armorer-global-arena -aircraft-maker-runs-afoul-us-with-china-radar.html?pagewanted $=$ all\&src $=$ pm $($ accessed June 10, 2013).

Pan, Zhenqiang. 2010. "China and the Middle East." In China's Growing Role in the Middle East: Implications for the Region and Beyond, ed. Abdulaziz Sager and Geoffrey Kemp, 73-95. Washington, DC: Nixon Center.

Ren, Zhaochun, Li Zhongfang, and Liu Zhiqiang. 2005. "Qianxi Xinjiang nai fazhan ruhe jiejian Yiselie naiye" [How to use the experience of Israel dairy industry in Xinjiang]. Herbivore Quarterly 128: 15-18.

Rivlin, Paul. 2011. The Israeli Economy from the Foundation of the State Through the 21st Century. New York: Cambridge University Press.

Rolnik, Guy, and Eran Azran. 2011. "Mission for Israel 2028: Stay Ahead of the Game." The Marker, January 12. www.haaretz.com/business /mission-for-israel-2028-stay-ahead-of-the-game-1.336519 (accessed June 1, 2012).

Schenker, David, and Christiana Lin. 2010. "China's Rise in the Middle East." Los Angeles Times, November 16.

Schiff, Ze'ev. 2005. "U.S. Orders Israel to Increase Control of Security Exports." Haaretz, June 12. www.haaretz.com/print-edition/news/u-s -orders-israel-to-increase-control-of-security-exports-1.161121 (accessed June 1, 2012).

Senor, Dan, and Saul Singer. 2009. The Start-Up Nation: The Story of Israel's Economic Miracle. New York: Twelve.

Shai, Aron. 2009. Sino-Israeli Relations: Current Reality and Future Prospects. Tel Aviv: INSS.

Shalhevet, Joseph. 2009. Sin VeIsrael: Hamada Besherut Hadiplomatia [China and Israel: Science in the service of diplomacy]. Kiryat Ono: Shamirim.

Shelah, Shmulik. 2010. "Huawei Menasa Lehasig Technologia Israelit Derech Gius Ovdim" [Huawei attempts to obtain Israeli technology through worker recruitment]. Globes, September 1-2.

Shichor, Yitzhak. 1998. "Israel's Military Transfers to China and Taiwan." Survival 40, 1: 68-91.

- 2005. "The U.S. Factor in Israel's Military Relations with China." China Brief 5, 12 (May 24): 7-9.

Simpfendorfer, Ben. 2010. "China's Historic Return to the Gulf." Foreign Policy, April 2. http://mideast.foreignpolicy.com/posts/2010/04/02/china _s_historic_return_to_the_gulf (accessed May 30, 2013).

SIPRI (Stockholm International Peace Research Institute) Arms Transfers Database. www.sipri.org/databases/armstransfers (accessed July 22, 2013). 
Tal, Israel. 1996. Bitachon Leumi: Meatim Mul Rabim [National security: Few against many]. Tel Aviv: Dvir.

Trofimov, Yaroslav. 1997. "Lost Contact." Far Eastern Economic Review, May 1, 52.

Wang, Hui. 2002. "Jiaoyu: Yiselie jingji tengfei de chibang" [Education: Wings for Israel's economic takeoff]. Journal of Hebei Normal University (Educational Science Edition) 4, 2: 94-96.

Wang, Xinming. 2002. "Yiselie de kexue jishu zhengce" [Science and technology policies of Israel]. Journal of Beijing Institute of Technology 4, 3: $62-64$.

Xia, Liping. 2005. "Cong waijiaobu kaifang dangan kan 20 shiji 50 niandai zhongyi jiechu shimo" [Contacts between China and Israel in the 1950s as seen from declassified files of the Chinese Ministry of Foreign Affairs]. Contemporary China History Studies 12, 3: 76-82.

Yegar, Moshe. 2004. Hamasa Haaroch LeAsia: Perek Betoldot Hadiplomatia shel Israel [The long journey to Asia: A chapter in the diplomatic history of Israel]. Haifa: University of Haifa Press.

Yeshayahou, Koby. 2011. "ChemChina Completes Makhteshim Agan Buy." Globes, October 17.

Zeevi, Nadav. 2008. "HaSinim Lo Sofrim Otanu" [The Chinese do not count us]. Maariv, August 8.

Zhang, Hongli, Zhang Wenbib, and Yu Xinde. 2007. "Yiselie jieshui nongye dui Zhongguo fazhan jieshui shengtai nongye de qishi" [Inspiration of the Israeli water-saving agriculture for the development of China's water-saving agriculture]. Ecological Industry Watch 10. 